\title{
COLLABORATIVE GOVERNANCE AND BENEFIT SHARING IN LIUWA PLAIN NATIONAL PARK, WESTERN ZAMBIA
}

\author{
Vincent R. Nyirenda ${ }^{1,2 *}$ and Bimo A. Nkhata ${ }^{3}$ \\ * Corresponding author, nyirendavr@hotmail.com. office phone/fax: +260 211278 335; mobile \\ phone +260977352035 \\ ${ }^{1}$ Department of Nature Conservation, Faculty of Science, Tshwane University of Technology, \\ Pretoria, South Africa \\ ${ }^{2}$ Directorate of Research, Planning, Information and Veterinary Services, Zambia Wildlife \\ Authority, Chilanga, Zambia \\ ${ }^{3}$ Monash University South Africa, Johannesburg, South Africa
}

ABSTRACT

Several models of public private partnerships have emerged focusing on wealth creation from high value resources, risk distribution through cost and benefit sharing, and prevention of loss of biodiversity through collaboration among members of the public and private sectors and local communities. However, there remain many information gaps underlying their social-ecological system performance. A case study of Liuwa Plain National Park $\left(3,660 \mathrm{~km}^{2}\right)$, western Zambia, to demonstrate the relationship between social capital and operational management by multiple partners between 2004 and 2011 was carried out. Literature review, expert knowledge and interviews of 57 informants with historical perspectives of the area were employed. We determined that social-economic-ecological gains and benefit distribution were influenced by the capacity of partners to negotiate collective interests. Intra and inter-partnership networking, social learning and differential capacity were also important factors.

KEYWORDS: public private partnerships, Liuwa Plain National Park, Zambia, benefit distribution

\section{INTRODUCTION}

The continued loss of biodiversity in most African countries has triggered policy attempts to experiment with various forms of partnerships in state owned protected areas (Fearnhead, 2009; Leverington et al., 2010; Lockwood, 2010). Though there has been proliferation of partnerships in Africa in the last few decades, literature on public private partnerships (PPPs) in protected areas remained limited (Farlam, 2005). Experiments with partnerships for protected area management are usually conducted in tandem with initiatives that seek to address park-neighbour conflicts and natural resources privatisation (Abbot et al., 2000; Barrow et al., 2000; Jones \& Murphree, 2001; Fearnhead, 2009). Partly driven by the notion of 'sustainable' institutions (Arrow et al., 1995), the main objective of these partnerships has been to manage the carrying capacity and social-ecological resilience of protected areas (Dearden \& Bennett, 2005). This involves collaborative and legally binding relationships based on shared responsibilities, resources, risks and benefits associated with protected area management within a defined period of time (Phillips, 2003). This objective was stressed at the 2002 World Summit on Sustainable Development in South Africa where civil societies and local communities were also explicitly recognised as being vital elements of traditional partnerships. The notion of partnerships has also been advanced through other international instruments such as the Convention on Biological Diversity (CBD) and particularly CBD Aichi targets that provide a platform for effective conservation, sustainable use and equitable sharing of benefits from natural resources (CBD, 1992 and 2011). In addition, community based natural resource management (CBNRM) fosters mutually beneficial partnerships, and collective management of natural resources by the state, local communities and other stakeholders (Suich et al., 2009).

The introduction of the theme of benefit sharing in discussions around partnerships has led to research efforts aimed at exploring ways to promote and assess progress towards effective benefit sharing (Farley \& Costanza, 2010; Howard, 2010; Nkhata et al., 2012), particularly in state owned protected areas. These efforts have incorporated analyses of broader aspects of benefit 
sharing initiatives such as social and human development goals, recognition of social justice and the uniqueness of each country's indigenous culture, and acknowledgment of the limits imposed by natural resource management (Gruber, 2010). These research efforts have further reflected growing recognition that benefit sharing initiatives cannot be successful in the absence of well-functioning governmental organisations, local community institutions and free-market mechanisms (Schuklenk \& Kleinsmidt, 2006; Wunder, 2007). Given the implications of diverse entities working together to accomplish common objectives and produce greater public value (Turton, 2008), such research efforts have been identified as belonging to a new area of inquiry focusing on the theme of collaborative governance (Brower et al., 2010). Although a significant amount of literature on the topic of collaborative governance does exist, there is still much to be learned from studying a diverse array of these systems to better understand how they function and what it takes for them to be successful (Pomeroy et al., 2010; Lockwood, 2010).

In this paper, we use the theory of collaborative governance to analyse the partnerships arrangements behind a benefit sharing scheme in Liuwa Plain National Park (LPNP) in Zambia. The case study provides useful information about how collaborative governance systems are designed and managed so as to function effectively in the context of benefit sharing. It presents an instructive example of the complexities of collaborative governance. The core objective of the partnership in LPNP had a public-oriented focus, while the benefit sharing programme was fundamentally a private sector initiative. Although both the public sector and local community actors actively participated in the partnership, questions still remain whether the private sector actor adopted a more competitive or collaborative approach in the benefit sharing programme. We argue that a collaborative governance perspective illustrates how, through the use of cross-sectoral partnerships, the level of stakeholder participation in benefit sharing schemes can be either enhanced or diminished. Therefore, the questions we consider in this paper are: How does collaborative governance enhance partnership performance of a state owned protected area such as LPNP? What is the role of partnership process in fostering implementation of the partnership? Are power relations and benefit sharing between parties important factors in a partnership for protected area management? We hypothesise that benefit sharing among the stakeholders influences performance of parts of the socio -ecological system in the LPNP.

\section{COLLABORATIVE GOVERNANCE PERSPECTIVE FOR EXPLORING PARTNERSHIPS FOR BENEFIT SHARING}

It is important to acknowledge that the term collaborative governance means different things to different people (Paavola et al., 2009). In the environmental sector, the term only emerged in the recent years in response to perceived failures in policy making and implementation (Phillips, 2003; Lockwood, 2010). The limitations of conventional command and control approaches to environmental problems played a critical role in the emergence of the term. We begin by breaking down the term into the two concepts on which it is based: collaboration and governance (Armitage et al., 2008).

Collaboration is essentially a social process that involves different actors working together to create more benefits than could be produced in unilateral settings (Hall, 1995; Imperial \& Kauneckis, 2003; Imperial, 2005). This process is founded on social relationships in which different actors influence each others' behaviour to promote common interests. The advantages of collaboration include reduced transactional costs, greater social-ecological resilience, and enhanced performance. Most researchers do not view collaboration as a 'fix-all' strategy for all social problems. As such, its significance is usually contingent upon a range of contextual, preferential and contingency factors (Wondolleck \& Yaffee, 2000; Imperial, 2005).

Governance is usually defined as 'the interactions among structures, processes and traditions that determine how power is exercised, how decisions are taken on issues of public concern, and how citizens or other stakeholders have their say' (Graham et al., 2003). Essentially, governance processes reveal the interactions amongst social actors, of which government is just a part (Olsson et al., 2004; Imperial \& Kauneckis, 2003). This process can be institutionalised at different levels of human interaction as a means of social coordination that engenders ordered rule, collective action (Ostrom, 1990; Stoker, 1998), and allows members of society to share power and make decisions (Berkes, 2009; Plummer \& Armitage, 2007).

From the above, collaborative governance can be conceived as societal arrangements where one or more public agencies directly engage non-state stakeholders in a collective decision-making process that is formal, consensus-oriented and deliberative and which aims to make or implement public policy or manage public programmes or assets (Armitage \& Plummer, 2010). 


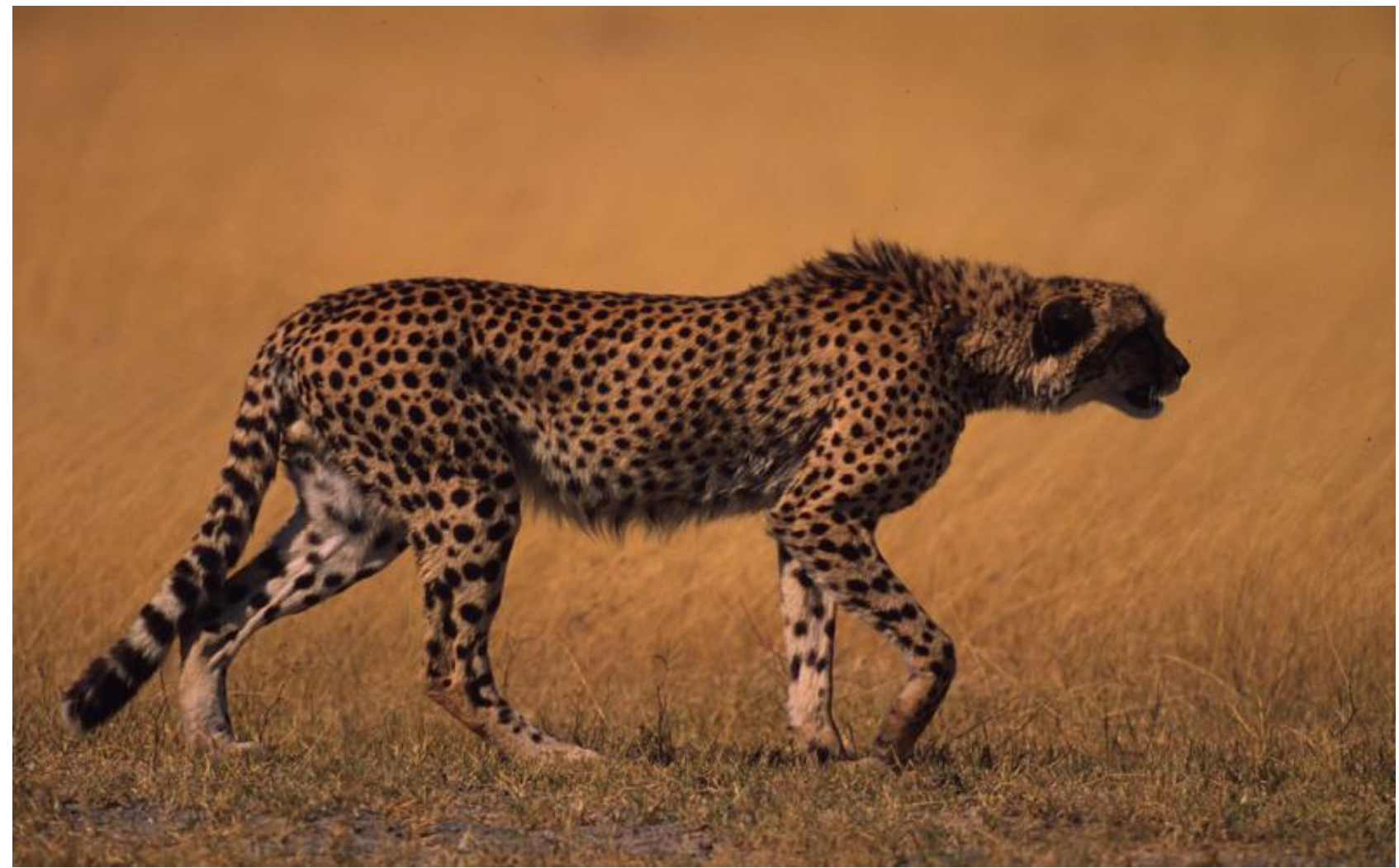

Cheetah (Acinonyx jubatus) @ Martin Harvey / WWF-Canon

\section{LIUWA PLAIN NATIONAL PARK: BIODIVERSITY, HISTORY AND MANAGEMENT}

LPNP $\left(3,660 \mathrm{~km}^{2}\right)$ is one of the 20 National Parks in Zambia. It is managed under Wildlife Act. No. 12 of 1998 by the Zambia Wildlife Authority (ZAWA). It is located in the western part of Zambia at $14^{\circ} 13^{\prime}-14^{\circ} 51^{\prime}$ S and $22^{\circ} 18^{\prime}-$ $22^{\circ} 55^{\prime} \mathrm{E}$, and is approximately $1050 \mathrm{~m}$ above sea level. The Park is characterised by human habitation; sedentary agriculturists practicing mixed farming system but living with wildlife. It is a generally flat grassland landscape, with seasonal floodplain where land is inundated from December to June. The floodplain is typified by grass species of Common Russet grass (Loudetia simplex) and Oats grass (Monocymbium ceresiiforme). Drier areas also develop termite mounds, forming wooded islands. Floodplain fringes have Zambesi Redwood (Baikiaea plurijuga) and Burkea (Burkea africana) dominated woodlands (van Gils, 1988; ZAWA, 2009).

Liuwa plain has a high biological diversity of conservation importance. According to Leonard (2005), the plain is important bird area for variety of bird species that include Wattled Cranes (Grus carunculatus), Southern-crowned Cranes (Balearica regulorum), Spurwinged Goose (Plectropterus gambensis), Caspian
Plovers (Charadrius asiaticus), Common Pratincoles (Glareola pratincola), Black-winged Pratincoles (Glareola nordmanni), Saddle-billed Storks (Ephippiorhynchus senegalensis), endemic Clapper Larks (Mirafra apiata jappi) and Pink-billed Larks (Spizocorys conirostris makawai). Fauna found in LPNP include migratory Blue Wildebeest (Connochaetes taurinus), Common Zebra (Equus burchelli), Tsessebe (Damaliscus lunatus), Red Lechwe (Kobus leche leche), Lion (Panthera leo), Wild Dog (Lycaon pictus), Cheetah (Acinonyx jubatus), Spotted Hyaena (Crocuta crocuta), Spotted-necked Otter (Lutra maculicollis), Oribi (Ourebia ourebi) and Southern Reedbuck (Redunca arundinum). The migratory Blue Wildebeest population of LPNP is probably second only from that of Serengeti in East Africa (Estes \& East, 2009). The plain is drained by two large rivers, Luambimba and Luanginga, dominated by Syzygium spp.

Liuwa plain was managed by King Litunga Lubosi Lewanika of the Lozi people as a hunting reserve until its establishment as National Park in 1972 (ZAWA, 2009). Management was through representatives of traditional leadership, the area chiefs and traditional advisors, indunas, responsible to the King Litunga. Upon establishment of the Park, management of natural resources was transferred to the government, by legal 
statute, and ZAWA was mandated to manage the Park. Local communities contested the ownership of the Park and its resources, some conspired with Angolan renegades from the neighbouring civil war, who were well equipped with firearms, to plunder the natural resources of Park. This situation went on for several years. As a consequence of this and inadequate resource protection, poor management and tourism infrastructure, and limited benefits to local communities residing in the Park, the government began to explore new partnerships towards more effective management.

\section{METHODS}

The study was motivated by information gaps in the underlying collaborative governance processes of many partnerships for benefit sharing schemes in Africa. We employed a literature review and expert knowledge coupled with focused interviews with 57 randomly selected informants. The authors have worked extensively in the wildlife sector of Zambia and have amassed technical knowledge in protected area management for over two decades. The informants were drawn from public sector organisations, private sector lead organisations, NGOs and local communities. An interview guide was used to generate historical perspectives of LPNP for the period between 2004 and 2011 (Annex 1). A case study approach, as described by Noor (2008), was used to develop a detailed account of the situation. Qualitative field research methods were used to establish the relationships between concepts and themes (Strauss \& Corbin, 1998) relating to social capital, events and mechanisms in collaborative governance and benefit sharing in the partnership. Protocols suggested by Bradburn et al. (2004) were used to guide interviews with knowledgeable people about LPNP. The scope of the case study was limited to partnership events and mechanisms, power relations and socio-economic-ecological performance.

\section{THE PARTNERSHIP ARRANGEMENTS UNDERLYING BENEFIT SHARING IN LIUWA PLAIN NATIONAL \\ PARK}

In Zambia, partnerships for protected area management can be traced back to the mid-1980s (Dalal-Clayton \& Child, 2003) and were aimed at addressing the poaching crisis during a time of limited state funding. Partnerships were based on emerging decentralisation policies for rural development and poverty reduction (Suich et al., 2009). They usually involved the government, philanthropic partners with interest in biodiversity conservation and local communities co-existing with natural resources. Partnerships were legitimised by legal instruments (e.g. Agreements or Memoranda of Understanding), running for varied periods, ranging from one to 20 years. Documentation on partnerships in protected areas was, however, limited compared to those in transport infrastructure and agricultural sectors.

The PPP in LPNP was characterised by five discrete but interlinked constituencies: LPNP as a part of the Upper Zambezi social-ecological system; the ZAWA as LPNP management agency; Strichting African Parks Foundation (SAPF) as a private partner; Barotse Royal Establishment (BRE) representing local communities in the Park; and a Partnership Board which governed the partnership on a company basis (Figure 1). The socialecological system of LPNP was characterised by high value common property resources such as migratory blue wildebeests, locally utilised through tourism and licensed hunting.

There are about 20,000 inhabitants in 432 villages in LPNP (Apse \& Seybert, 2010), who were originally sanctioned by King Litunga to keep game animals. In 1972 when the hunting reserve was established as LPNP, the government allowed human settlements to continue as the local communities were previously entrusted by their traditional leadership to manage natural resource. However, as noted above in the period following the establishment of the Park, natural resources were depleted due to poorly funded operations and disenfranchised local communities. In May 2004, the PPP was established between ZAWA, SAPF and BRE through a Management Agreement (relationship 1, 2 and 3 in Figure 1) to help resolve these problems. The existence of local communities in the Park who were managing wildlife prior to establishment of the Park was the basis for co-management and shared governance over the Park resources. BRE, working though the traditional chiefs and indunas, liaise with local communities on their inspirations and challenges and worked in turn with ZAWA and SAPF, to collectively discuss and resolve issues. Issues of equity are dealt with in a transparent manner by disclosure during public and Board meetings. The chiefs and indunas are accountable to both King Litunga and local communities through regular feedback (e.g. through local meetings).

The 2004 Agreement aimed at providing financial, ecological and political sustainability for the Park governed by the Partnership Board. The main components of Agreement are given in Annex 2. Operational management function was relinquished to SAPF by the government. Three distinctive levels of 


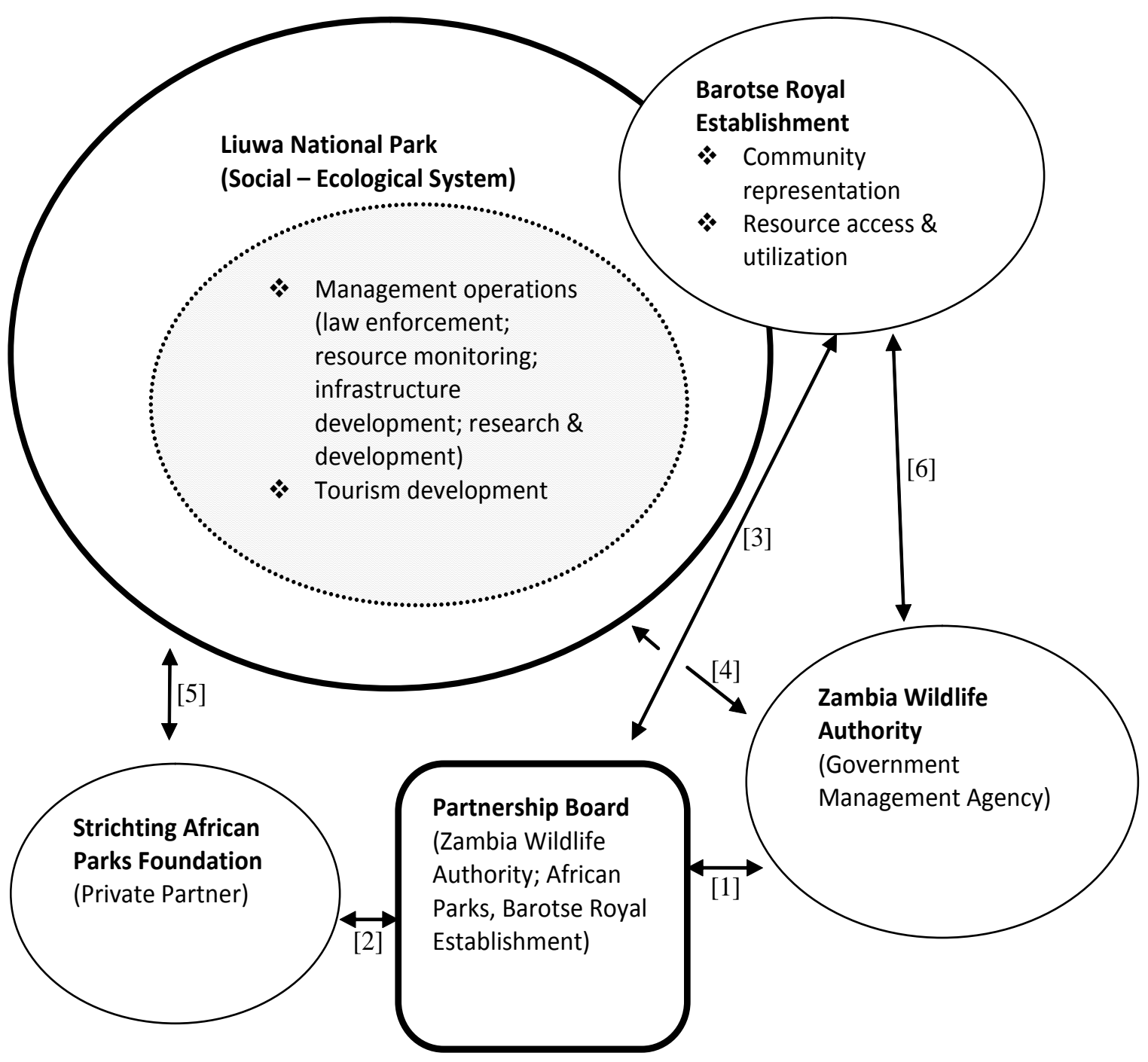

Figure 1: Operational framework of public private partnership in Liuwa Plain National Park, 2004 -2011.

interactions were identified for the entire partnership: at contractual level relating to the Agreement, decisionmaking level relating to consensus made inter-party and operational level relating to activities in the field.

Incentives were a central activity and the basis for collective action. ZAWA maintains the regulatory roles as the employer of the Park's law enforcement staff, supplier of animals to restock the Park (relationship 4) and provides relevant legislative interpretation to the Park management team. SAPF is responsible for upgrading wildlife tourism development, valorisation of natural resources, transferring of income generated to benefit local communities and facilitate preservation of cultural heritage (relationship 5). In terms of income generation, local communities manage four rice grinding mills and five community campsites. They retain camping fees, sell firewood to tourists, charge for traditional cultural performances at the campsites, weave and sell baskets made from raw materials obtained in the Park, catch fish in designated Park fish ponds free of charge and are allowed to hunt animals in the surrounding Upper West Zambezi Game Management Area on 'resident' licences issued by the government. The other main role for local communities is conducting resource protection and monitoring through village scouts, trained by SAPF. In order to secure funds, SAPF was mandated to raise substantial funding from cooperating partners and recruit technical personnel for park operations and tourism development. Further, SAPF was responsible for animal population growth, capital asset, wildlife translocations, resource economics and local leadership. Recognising the importance of garnering conservation support, BRE was involved at the policy making level, facilitating community projects and participating in conservation programmes (relationship 6). External support to the partnership and legitimisation of its operations were indirectly applied via SAPF. 


\section{PARTNERSHIP PROCESSES AND POWER RELATIONS}

In the process of establishing the LPNP partnership, lessons learnt previously within Southern Africa (Fearnhead, 2009) on institutional experiences of partners on, for instance, partnership administrative structures and park management systems development resulted in a shorter 'learning curve'.

Negotiation processes for the partnership development lasted for more than one year. Political and traditional BRE leadership played a critical role in the establishment and maintenance of the partnership. However, the seemingly top down approach of the partnership establishment processes undermined ZAWA's participation. SAPF articulated, in substance and process, roles and responsibilities while other partners struggled with interpretation of the provisions of the partnership. More positively these matters were redressed through partnership communication channels, including regular quarterly Board meetings, though these efforts were protracted due to officialdom within ZAWA (Annex 2). Regardless of the challenges, high confidence by private donors in SAPF resulted in substantial startup and implementation funds. Early in the partnership process, the resources acquired were spent in offsetting high transaction costs of establishing and implementing the protected area management partnership, sensitising and training stakeholders, providing operational logistics and personnel placements.

Though initially parties conceded to the Board's decision making, unbalanced representation caused skewed power relations at contractual, decision making and even operational level. Uneven power relations and rights favoured SAPF, due to what turned out to be a poorly and inequitably negotiated partnership contract. ZAWA's decision making mostly prevailed at contractual level, hence ZAWA embarked on re-engaging partners to strengthen decision making provisions in the operational management of LPNP while enfranchising SAPF.

Some people also felt that partnership negotiations were not adequate. During the implementation of Agreement, partnership decision making was undertaken in quarterly meetings of the Board. Ground rules for implementation of the partnership included upholding by all parties decisions agreed during the meetings, openness of each party to the other, the agreement of definitive channels of communication and pursuing amicable means to resolve any developing conflict. Despite the initial problems, a planned independent performance evaluation in the first five years of the PPP gave a positive assessment of partnership credibility (Apse \& Seybert, 2010).

The partnership operates at a strategic business unit, where funds raised from park fees, tourism and private donations are retained for conservation and rural development, with the aim that operations became cost neutral or profit making. Local communities retained revenues from various income generating activities and community projects noted above. Financial benefits' sharing on company profits is based on partner shareholding with 70 per cent going to SAPF and 30 per cent to BRE. No revenues generated in the Park were shared with ZAWA, although they have expressed a wish to be included as a shareholder in the partnership.

The partnership adopted an adaptive management approach. Through innovations and competition, the management team was able to learn from other parks within Zambia and the region on how they were managing for instance park law enforcement, tourism development, infrastructure development and community relations. This type of cooperative learning allowed the testing of various approaches and allowed the management team to adapt operations to meet specific circumstances. For example, with an increased emphasis on discipline, provision of incentives and a targeted patrol system, the management team of LPNP were able to effectively manage environmental crimes in the Park. At an operational level, marketing and planning, whose outputs included business and land use plans, were core elements in guiding management decisions. The capture of benefits by elites was avoided by widespread local participation instead of targeting interventions to a few selected influential individuals. The main checks and balances put in place for avoidance of capture of benefits by elites were openness and transparency with local communities, through notifying BRE on benefit distribution.

\section{ECOLOGICAL PERFORMANCE}

As noted, prior to partnership establishment, large mammal populations were overhunted in LPNP by Angolan armed factional forces and fugitive refugees. The partnership restored the fragile ecosystem and ecosystem processes that threatened the traditional cultural and ecological integrity of LPNP. Restoration activities included wildlife re-introductions of major species such as Eland (Taurotragus oryx) (49), Cape Buffalo (Syncerus caffer) (50) and Lion (2). Increased anti-poaching activities; including use of investigation 
Table 1: Changes in animal populations prior to and during the Liuwa Plain National Park partnership

\begin{tabular}{|c|c|c|c|c|c|c|}
\hline \multirow[b]{2}{*}{ Wildlife species } & \multicolumn{2}{|c|}{$\begin{array}{l}\text { Prior to partnership } \\
\text { implementation }\end{array}$} & \multicolumn{4}{|c|}{ During partnership implementation } \\
\hline & $1991^{1}$ & $\begin{array}{c}\text { December } \\
2001^{2}\end{array}$ & $\begin{array}{c}\text { December } \\
2004^{3}\end{array}$ & $\begin{array}{l}\text { April } \\
2007^{4}\end{array}$ & $\begin{array}{l}\text { April } \\
2009^{5}\end{array}$ & $\begin{array}{l}\text { April } \\
2011^{6}\end{array}$ \\
\hline Plains Zebra (Equus burchelli) & 771 & 2,500 & 2,706 & 3,977 & 4,992 & 4,431 \\
\hline Oribi (Ourebia ourebi) & 463 & 116 & 1,241 & 1,411 & 911 & 935 \\
\hline Red Lechwe (Kobus leche leche) & 534 & 215 & 966 & 1,167 & 1,405 & 1,272 \\
\hline Tsessebe (Damaliscus lunatus) & 7,674 & 300 & 430 & 501 & 1,231 & 878 \\
\hline Blue Wildebeest (Connochaetes taurinus) & 29,369 & 15,000 & 23,455 & 33,088 & 36,494 & 42,717 \\
\hline Wattled Crane (Bugeranus caruncalatus) & - & 588 & - & - & 1,695 & 1,717 \\
\hline
\end{tabular}

Notes: Adapted from Viljoen (2011) for the period between 1991 and 2011 ( ${ }^{1}$ Tembo \& Saiwana, 1991; ${ }^{2}$ Kamweneshe et al., 2003; ${ }^{3,4,5}$ \& 6 Viljoen, 2005; 2007; 2009; 2011)

and intelligence information, conducting of regular 'village sweeps' (i.e. systematic and legitimised search for illegal items such as firearms) and field patrols. Regular animal censuses and population monitoring have been conducted since the beginning of the partnership.

Table 1 depicts the changes in animal populations from baselines in 1991 and 2001, compared with period of partnership. The annual operational expenditure reached US\$230 per $\mathrm{km}^{2}$ for LPNP in 2011 from less than US\$101 per $\mathrm{km}^{2}$ prior to the partnership. In 2007, a management effectiveness tracking tool for protected areas in Zambia (METTPAZ) assessment confirmed through the use of scorecards and nominal rating that LPNP was effectively managed by the partnership, and was effective against threats such as poaching, wild fires, human encroachment and deforestation (Mwima, 2007). As a result of partnership conservation efforts, tourist arrivals in LPNP increased and averaged at 440 tourists per annum from 291 tourists in 2003 (Apse \& Seybert, 2010). Further, establishment of Transfrontier Conservation Area between Mussuma Area in Angola and LPNP in Zambia is currently underway.

\section{SOCIO-ECONOMIC PERFORMANCE}

Local communities in LPNP received several financial and non-financial benefits resulting from the LPNP partnership between 2004-2011. The transfer of benefits for rural development was linked to wildlife conservation; as a result project development by local communities is increasingly supporting Park sustainability. The benefits inter alia include: annual jobs increased by 733 per cent from 12 jobs in 2004 to 100 jobs by 2011 for local people in low volume, high value' tourism development. A total of 37 pupils received school scholarships. At Lukoko School, one block of two classrooms and two teachers' houses were constructed. Six campsite attendants' houses were built. A reforestation programme in settled areas included the supply and planting of 700 fruit and indigenous trees (plus 82 watering cans), 500 of which were planted on the school grounds of 18 local schools. Kalabo High School computer room and V-Sat internet facility were constructed, and thirty computers donated. Twenty-six boreholes were sunk for domestic water supply to 26 villages and schools. Three water wells were dug at the three community campsite at Lyangu, Kwale and Katoyana. Four hundred solar cookers were distributed for local communities' use, to help address the unsustainable harvesting of fuel wood. In addition, 79 energy saving stoves were supplied to local community members for use. Four rice grinding mills were distributed for use by local communities. Eleven women's clubs were registered, and were financially and technically supported in skills and product development. LPNP inter-schools drama festivals, community training in conservation and the Liuwa Environmental Education Programme (LEEP) involving 5,00o school children were facilitated and all focused on a strong outreach component. Core conservation values such as traditional fishing and animal grazing grounds were protected, and the historical Libonda Kuomboka and Liyenya annual traditional ceremonies were promoted through provision of financial benefit transfers.

These projects were funded from revenues generated from enterprises such as tourism community campsites and from donor funds. Over the years substantial funding has come from donors, and funds generated from other revenue streams in LPNP are steadily increasing. The management team administer the funds through Liuwa Community Development Fund (Annex 2). 


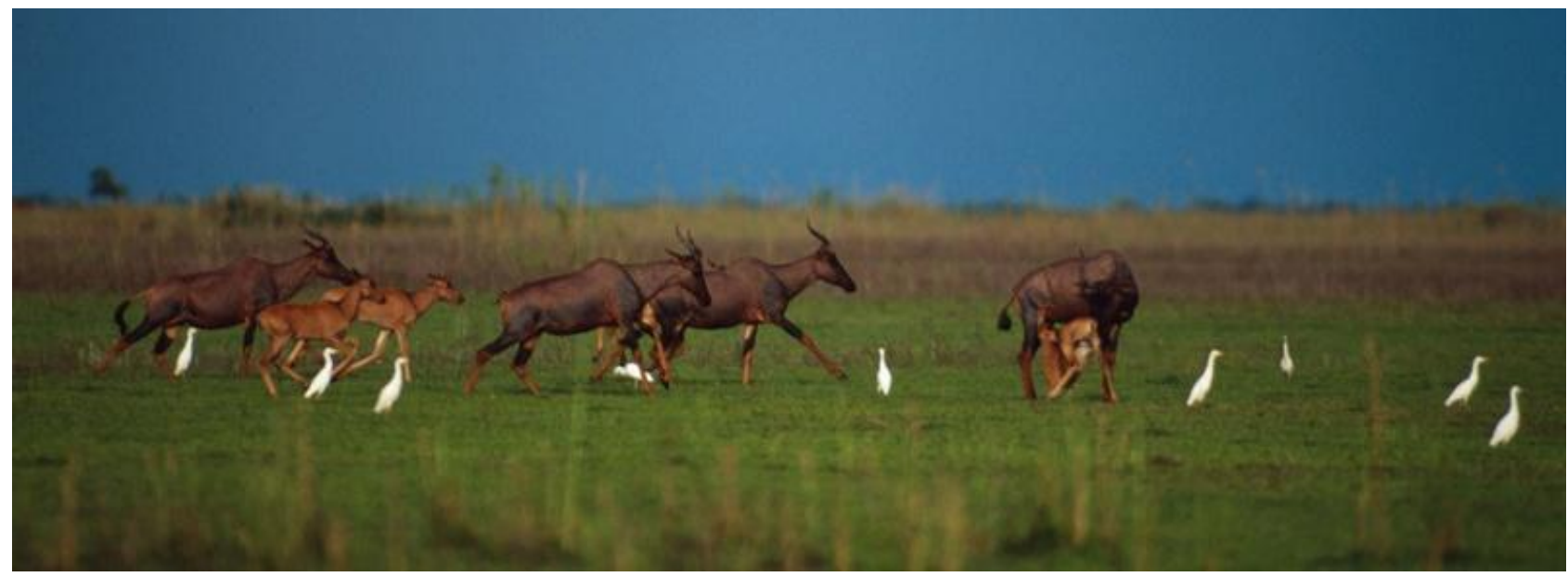

Tsessebe (Damaliscus lunatus) (C) Roger Leguen / WWF-Canon

\section{CONCLUDING REMARKS}

The collaborative governance of LPNP in form of a tripartite partnership of ZAWA, SAPF and BRE has contributed to the positive performance of Park management. The period assessed (2004-2011) is relatively short but it provides an indication of the impact of such a partnership when collaborative governance is integrated with benefit sharing mechanisms. The LPNP partnership is dynamic but could have probably achieved more if the design was better negotiated by government and BRE. Even though the partnership negotiations lasted over a year, allowing for lengthy but effective negotiations can maximise ownership by stakeholders and minimise future bottlenecks in the progression of a partnership (Roe et al., 2001).

As the partnership formed a nexus of conservation and rural development, it drew participation from many different stakeholders, whose successful benefit depended on the strength of fair collective bargaining of their interests. Due to the failure by ZAWA and BRE to comprehensively bargain at the beginning of the partnership, however cooperative trust reduced over the years. According to Glasbergen (1995), effective performance of protected area management and benefit equitable sharing is linked to levels of trust between partners. Hence, the need to constantly discuss and resolve emerging issues through mechanisms such as the Partnership Board and stakeholder meetings. Nevertheless, the SAPF demonstrated its capacity to raise funds from cooperating partners and generate revenues from LPNP. However, since much of the funding utilised for Park management and community projects remains largely donor contributions, sustainable financing plans will need to emphasis further generation of revenues from local LPNP partnership processes.
Since the establishment of the partnership, benefits have been generated and transferred to stakeholders. The Park's profile has improved but stakeholder expectations still remain very high based on the promises made in respect to enhancing biodiversity, infrastructure, tourism and community development at the beginning of the partnership. However, in order to generate substantial profits further enhancement of the resource base, tourism and management infrastructure, community relations and community livelihoods is recommended. This agenda will require parties to further fine tune their responsibilities and accountability. In particular, ZAWA and BRE will need to be robust enough as 'institutions of sustainability' to be able to fairly and firmly negotiate, and counteract external influences.

\section{ACKNOWLEDGEMENT}

The authors are grateful to Park Manager, Raquel Filgueiras Seybert; Park Ranger, Jarton Shawa of Liuwa Plain National Park, and Former Area Warden, Agness Shawa, for their contribution during data collection. The study was supported by Zambia Wildlife Authority. A number of participants responded to study questions.

\section{ANNEX 1: INTERVIEW GUIDE ON COLLABORATIVE GOVERNANCE AND BENEFIT SHARING IN LIUWA PLAIN NATIONAL PARK FOR THE PERIOD \\ BETWEEN 2004 AND 2011 \\ A: Preliminaries}

1. Disclosure of the purpose and contents of the interview

2. Confirmation of the participants' historical knowledge of the Park

3. Obtaining participants' consent

4. Assuring participants of confidentiality of their input

5. Personal details and affiliations 


\section{B: Collaborative governance and benefit sharing}

1. Elucidate, in timeline, natural resource management in the Park prior and after partnership establishment. Note the changes in who managed the resources, how they managed them and impacts of their management.

2. Obtain factors that could have brought about changes in the management arrangements.

3. Establish what transpired during the process of establishing the partnership and what followed thereafter. This should include elements of partnership negotiations, heads of agreement/ contract, activities and implementation modalities.

4. Ascertain who held and exercised the power over management and utilization of natural resources, and benefit sharing in the partnership. To what degree they exerted such power. [Where did the 'active' power lie?]

5. Find out how partners related to each other vis-àvis the partnership Agreement.

6. Establish what were the benefits of the partnership and how they were generated and, subsequently, how they were shared among the parties.

7. What were the roles and responsibilities of each party and how were they implemented?

8. Obtain the description of ecological and socioeconomic performance attributed to the partnership.

N.B.: Probe further on each of the above issues depending on the willingness of the participant to be interviewed more, where necessary.

\section{ANNEX 2: MAIN COMPONENTS OF PARTNERSHIP AGREEMENT IN LIUWA PLAIN NATIONAL PARK FOR LOCAL GOVERNANCE}

- $\quad$ The partnership works under a Company called African Parks Zambia, established through the Companies Act which provides shareholding among parties (SAPF and BRE). ZAWA, however, has in the recent years made a claim to have shareholding position in the Company.

- The partnership Board constitutes representation from SAPF (4), Barotse Royal Establishment (2) and ZAWA (1). It is the main governance body, with legal standing. The Chairman is appointed by SAPF from four of its representative Board members. Decisions are by consensus. Management activities are conducted by a combined team on the ground. The team is responsible for such activities as resource protection, tourism development, infrastructure development, community support and management of community relations.

- The Agreement's jurisdiction is over the Park and does not include areas surrounding it. In practice, however, the partnership operations have spilled over to the surrounding areas especially in the area of community projects such as social amenities and human wildlife conflict mitigation.

- $\quad$ The Agreement advocates regular communication among stakeholders, ZAWA, SAPF and BRE, mainly in writing. In practice, besides sharing written operational reports, presentations are also made when necessary and agreed by the partners. For instance, BRE representatives locally known as Silalo Induna Committee report to their constituencies (area committees) and the Board on various community issues and projects, and so do field team of SAPF and ZAWA on park operations. At times, however, internal communication and officialdom among some members of parties have been challenging.

- The Agreement provides for establishment of a BRE Cultural and Support Fund for support of BRE cultural and administrative activities and Liuwa Community Development Funds (LCDF) to speedily support anti-poaching and community projects. Management team administers both funds. Further, penalties in form of deductions from LCDF are implemented on monthly basis in accordance with the Agreement when poaching incidents or other unlawful activities by the local communities occur in the Park. These measures are supported by the local communities and prove to be effective in curbing biodiversity loss in LPNP.

- $\quad$ The Agreement devolves management authority to a management team but also further gives the rights such as granting of tourism concessions to SAPF. In practice, based on the Agreement, ZAWA is consulted and approves policy decisions such as granting of tourism concession prior to implementation.

\section{REFERENCES}

Abbot, J., F. Ananze, N. Barning, P. Burning, E. de Merode, A. Dunn, E. Fuchi, E. Hakizumwami, C. Hasse, R. Mwinyihali, M. Sani, D. Thomas, P. Trench and R. Tshombe (2000). Promoting partnerships: managing wildlife resources in Central and West Africa. Evaluating Eden series no. 3. London: International Institute for Environment and Development. 
Apse, C. and R. Seybert (2010). African Parks management of Liuwa Plain National Park. Lusaka, Zambia: The Nature Conservancy.

Armitage, D. and R. Plummer. (Eds.) (2010). Adaptive Capacity and Environmental Governance. Berlin Heidelberg, Germany: Springer-Verlag

Armitage D., M. Marschke and R. Plummer (2008). Adaptive co-management and the paradox of learning. Global Environmental Change 18(1): 86-98

Arrow, K., B. Bolin, R. Constanza, P. Dasgupta, C. Folke, C. Holling, B. Jansson, S. Levin, K. Malër, C. Perrings and D. Pimentel (1995). Economic growth, carrying capacity and the environment. Science 268: 520-521.

Barrow, E., H. Gicholi and M. Infield (2000). Rhetoric or reality? a review of community conservation policy and practice in East Africa. Evaluating Eden series no. 5. London: International Institute for Environment and Development.

Berkes, F. (2009). Evolution of co-management: role of knowledge generation, bridging organisations and social learning. Journal of Environmental Management 90(5): 1692-1702.

Bradburn, N., S. Sudman and B. Wansink (2004). Asking questions: the definitive guide to questionnaire design for market research, political polls, and social and health questionnaires. California: Jossey-Bass.

Brower, A., S. Coffey and B. Peryman. (2010). Collaborative Environmental Governance Down Under, in Theory and in Practice. Lincoln Planning Review, North America, 2, Aug. 2010. Available at: http://journals.lincoln.ac.nz/ index.php/LPR/article/view/533/389>. Accessed on 2 March 2013.

CBD (1992). Convention on Biological Diversity. Available at http://www.cbd.int/convention/convention.shtml. Accessed on 3 March 2010.

CBD (2011). Strategic Plan for Biodiversity 2011-2020 and the Aichi Targets: 'Living in Harmony with Nature'. http:// www.cbd.int/doc/strategic-plan/2011-2020/Aichi-TargetsEN.pdf. Accessed on 1 February 2013.

Dearden, P. and M. Bennett (2005). Trends in global protected area governance. Environmental Management 36(1):89100.

Dalal-Clayton, B. and B.Child (2003). Lessons from Luangwa: the story of the Luangwa Integrated Resource Development Project, Zambia. Wildlife and Development Series 13. London: International Institute for Environment and Development.

Estes, R.D. and R. East (2009). Status of the wildebeest (Connochaetus taurinus) in the wild, 1967-2005. Working Paper No. 37. New York, USA: Wildlife Conservation Society.

Farlam, P (2005). Assessing public private partnership in Africa. Nepad policy focus series number 2. Pretoria: SAllA.

Farley, J. and R. Costanza (2010). Payments for ecosystem services: From local to global. Ecological Economics 69: 2060-2068.

Fearnhead, P. (2009). Privately managed protected areas. In: Suich, H., B. Child, and A. Spenceley (eds), Evolution and innovation in wildlife conservation: parks and game ranches to transfrontier conservation areas. London: Earthscan. p 409-424
Glasbergen, P. (1995). Managing environmental disputes: network management as an alternative. Boston: Kluwer Academic publishers.

Graham, J., B. Amos and T. Plumptre (2003). Governance principles for protected areas in the $21^{\text {st }}$ Century. A Discussion Paper. Ottawa: Institute on Governance in Collaboration with Parks Canada and Canadian International Development Agency.

Gruber, J. S. (2010). Key principles of community-based natural resource management: a synthesis and interpretation of identified effective approaches for managing the commons. Environmental Management 45 (1): 52-66.

Hall, A.W. (2006). Global experience on governance. In: Turton, A.R., H. Hattingh, G. Maree, D. Roux, M. Claasen and W. Strydom (eds), Governance as a trialogue: government-society-science in transition. Berlin: Springer.

Hardin, G. (1968). The tragedy of the commons. Science 162: 1243-1248.

Howard, J.L. (2010). Managing for justice in community-based water planning: a conceptual framework. Environmental Conservation 37 (3): 356-363

Imperial, M.T. (2005). Using collaboration as a governance strategy: lessons form six watershed management programs. Administration and Society 37(3): 281-320

Imperial, M.T. and D. Kauneckis (2003). Moving from conflict to collaboration: lessons from the Lake Tahoe experience. Natural Resources Journal 43(4): 1009-1005.

Jones, B. and M. Murphree (2001). The evolution of policy on community conservation in Namibia and Zimbabwe. In: Hulme, D. \& M. W Murphree (eds), African wildlife and African livelihoods: the promise and performance of community conservation, Oxford, UK: James Currey. p 3858.

Kamweneshe, B., R, Beilfuss and K. Morrison (2003). Population and distribution of Wattled Cranes and other large waterbirds and large mammals on the Liuwa Plains National Park, Zambia. Lusaka: Zambia Crane and Wetland Conservation Project.

Leonard, P. (2005). Important bird areas in Zambia. Lusaka: The Zambian Ornithological Society.

Leverington, F., K.L. Costa, H. Pavese, A. Lisle and M. Hockings (2010). A Global Analysis of Protected Area Management Effectiveness. Environmental Management 46: 685-698.

Lockwood, M. (2010) Good governance for terrestrial protected areas: A framework, principles and performance outcomes. Journal of Environmental Management 91: 754-766.

Mwima, H. K. (2007). Management effectiveness tracking tool for protected areas. Lusaka: Ministry of Tourism, Environment and Natural Resources.

Nkhata, B. A., A. Mosimane, L. Downsborough, C. Breen and D.J. Roux (2012). A typology of benefit sharing arrangements for the governance of social-ecological systems in developing countries. Ecology and Society 17:

Noor, K.B. M. (2008). Case study: a strategic research methodology. American Journal of Applied Science 5(11): 1602-1604.

Olsson, P., C. Folke and F. Berkes (2004). Adaptive comanagement for building resilience in social-ecological systems. Environmental Management 34: 75-90.

Ostrom, E. (1990). Governing the commons: the evolution of institutions for collective action. New York: Cambridge University Press. 
Paavola J., A. Gouldson and T. Kluvankova-Oranska (2009). Interplay of actors, scales, frameworks and regimes in the governance of biodiversity. Environmental Policy and Governance 19: 148-158.

Phillips, A. (2003). Turning ideas on their head: the new paradigm for protected areas. The George Wright Forum 20(2): 8-32.

Plummer, R. and D. Armitage (2007). A resilience-based framework for evaluating adaptive co-management: linking ecology, economics and society in a complex world. Ecological Economics 61: 62-74.

Pomeroy, R., L. Garces, M. Pido and G. Silvestre (2010). Ecosystem-based fisheries management in small-scale tropical marine fisheries: emerging models of governance arrangements in the Philippines. Marine Policy 34: 298308.

Roe, D., M. Grieg-Gran and W. Schalken (2001). Getting the lion's share from tourism: private sector - community partnership in Namibia. Poverty, inequality and environment series 1 . London: International Institute for Environment and Development.

Schuklenk, U. and A. Kleinsmidt (2006). North-South benefit sharing arrangements in bioprospecting and genetic research: a critical ethical and legal analysis. Developing World Bioethics 1471-8847 (online): doi:10.1111/j.14718847.2006.00149.x. Accessed on 15 August 2011.

Stoker, G. (1998). Governance as theory: five propositions. International Social Science Journal 50(155): 17-28.

Strauss, A. and J. Corbin (eds.) (1998). Basics of qualitative research: techniques and procedures for developing grounded theory. Thousand Oaks, California: Sage Publications.

Suich, H., B. Child and A. Spenceley (eds.) (2009). Evolution and innovation in wildlife conservation: parks and game ranches to transfrontier conservation areas. London: Earthscan.

Tembo, A. and L. Siawana (1991). Abundance, biomass and distribution of common herbivores of the Liuwa National Park, Zambia. Chilanga: Zambia National Parks \& Wildlife Service.

Turton, A. (2008). A South African perspective on a possible benefit sharing approach for trans-boundary waters in the SADC Region. Water Alternatives 1(2):180-200.

van Gils, H. (1988). Environmental profile of western province, Zambia. Mongu, Zambia: Provincial Planning Unit.
Viljoen, P. (2005). Liuwa Plain National Park aerial wildlife survey - December 2004. White River: African Parks Network.

Viljoen, P. (2007). Liuwa Plain National Park aerial wildlife survey - April 2007: survey result summary. White River: African Parks Network.

Viljoen, P. (2009). Liuwa Plain National Park aerial wildlife survey - April 2009: survey result summary. White River: African Parks Network.

Viljoen, P. (2011). Liuwa Plains National Park and adjacent Game Management Area, Zambia aerial wildlife survey. White River: African Parks Network.

Wondolleck, J.M. and S.L. Yaffee (2000). Making collaboration work: lessons from innovation in natural resource management. Washington, DC, US: Island Press.

Wunder, S. (2007). The efficiency of payments for environmental services in tropical conservation. Conservation Biology 21:48-58.

ZAWA (2009). Land use plan for Liuwa Plain National Park. Chilanga, Zambia: ZAWA.

\section{ABOUT THE AUTHORS}

Vincent R. Nyirenda (BSc, M.Sc, PhD) has specialised in environmental systems and nature conservation with professional experience at local, regional and international levels. He has held senior portfolios in wildlife and environment sectors in government and international organisations. $\mathrm{He}$ published several scientific publications in peer reviewed journals.

Bimo A. Nkhata (M.Sc, PhD) is Associate Professor in Environment and Development. He has extensive local, regional and international professional experience in protected areas management. He has served in wildlife and environment sectors at senior portfolios in government, international organisations and universities. He published several scientific publications in peer reviewed journals.

\section{RESUMEN}

Han surgido varios modelos de asociaciones público-privadas centradas en la creación de riqueza a través de recursos de alto valor, de la distribución del riesgo a través de la participación en los costos y beneficios, y de la prevención de pérdida de biodiversidad a través de la colaboración entre los miembros de los sectores público y privado y las comunidades locales. Empero, aún subsisten muchas lagunas de información en cuanto al desempeño de su sistema socioecológico. Se realizó un estudio de caso sobre el Parque Nacional de Liuwa Plain $\left(3660 \mathrm{~km}^{2}\right)$, en la zona occidental de Zambia, para demostrar la relación entre el capital social y la gestión operativa por múltiples asociados entre 2004 y 2011. Se utilizaron análisis biográficos, conocimientos especializados y entrevistas a 57 participantes con perspectivas históricas sobre el área. Determinamos que tanto los beneficios económicos, ecológicos y sociales como la participación en ellos se vieron influenciados por la capacidad de los asociados para negociar los intereses colectivos. La creación de redes de asociaciones inter e intrainstitucionales, el aprendizaje social y la capacidad diferencial también fueron factores importantes. 


\section{RÉSUMÉ}

Plusieurs modèles de partenariats public-privé ont fait leur apparition, axés sur : la création de richesses à partir de ressources à forte valeur ajoutée, la répartition des risques grâce au partage des avantages et des coûts, et la prévention de la perte de la diversité biologique. Ces partenariats ont été possibles grâce à une collaboration entre membres du secteur public et privé et les communautés locales. Cependant, peu d'informations sont disponibles quant à leur performance socio-écologique. Une étude de cas a été réalisée entre 2004 et 2011 dans le parc national de Liuwa Plain $\left(3660 \mathrm{~km}^{2}\right)$, en Zambie occidentale, afin de démontrer la relation entre le capital social et la gestion opérationnelle par des partenaires multiples. Cette étude s'est basée sur un examen des études publiées, les connaissances d'experts ainsi que des entretiens menés auprès de 57 répondants, en s'appuyant sur une perspective historique de la zone concernée. Nous avons ainsi pu déterminer que les gains et la répartition des avantages en termes socio-économiquesécologiques étaient déterminés par la capacité des partenaires à négocier des intérêts collectifs. Par ailleurs, la mise en réseau au sein et à l'extérieur du partenariat, l'apprentissage social et les capacités différentielles s'avèrent être également des facteurs importants. 